\title{
A Clinical Review of Zika Virus (ZIKAV)
}

\author{
Muhammad Hashim Raza ${ }^{1 *}$, Sarfraz Hussain², Muhammad Abdul Rehman Tanveer ${ }^{3}$, Ayesha Zaman ${ }^{4}$ \\ ${ }^{1}$ Department of Bioinformatics and Biotechnology, International Islamic University, Islamabad, Pakistan.44000 \\ ${ }^{2}$ Department of Microbiology, University of Veterinary and Animal Sciences, Lahore, Pakistan.54000 \\ ${ }^{3}$ Department of Microbiology, University of Central Punjab, Lahore, Pakistan.54000
}

${ }^{4}$ Department of Microbiology, Abbottabad University of Science and Technology, Abbottabad, Pakistan.22010

\author{
A R T I C L E I N F O \\ Article history: \\ Received: 08 December, 2017 \\ Accepted: 12 February 2017 \\ Online: 25 February, 2017
}

Keywords:
ZIKAV
ZIKA Virus
ZIKV
Review of ZIKA Virus

\section{Introduction}

Zika virus is a flavivirus and it was first isolated in 1947 from a febrile rhesus macaque monkey in the Zika Forest of Uganda. Subsequently it was identified in Aedes africanus mosquitoes from the same forest [1]. In 1954 the first three cases of human infection were reported in Nigeria [2] and epidemics have

Corresponding Author: Muhammad Hashim Raza, Department of Bioinformatics and Biotechnology, International Islamic University, Islamabad, Pakistan.44000 Email: hashim.msbt247@iiu.edu.pk

\begin{abstract}
A B S T R A C T
Zika virus (ZIKAV) is a flavi-virus, first isolated in 1947 in the Zika Forest of Uganda. ZIKAV is a positive-sense single-stranded RNA virus. ZIKAV is made up of two noncoding regions (5' and $\left.3^{\prime}\right)$ that verge an open reading frame, which put into code a polyprotein smote into the capsid, precursor of membrane, envelope, and 7 nonstructural proteins. Inoculation of a human host is by Mosquito. After cellular entry, the virus enters skin cells through cellular receptors, enabling migration to the lymph nodes and blood circulation. ZIKAV may also enter to skin fibroblasts, keratinocytes, and immature dendritic cells. Several entry and adhesion factors enable infection, and cellular autophagy, needed for flaviviral replication. Transmission is by infected mosquito during a blood meal. After endorsement, the virus replicates and is pass on to a reservoir animal at the next blood mealtime. ZIKAV is also transmitted via congenital, perinatal, and sexual, possible transmission by blood transfusion, animal bite and intrauterine transmission. Transmission via breast-feeding has not been reported. Incubation period from mosquito bite to symptom commencement is 3-12 days. Infection is likely subclinical in $80 \%$ of cases. Symptoms, which last for almost two to seven days include fever, conjunctivitis, arthralgia, myalgia, and pervasive rash, which may be itchy. Headache, retro-orbital pain, peripheral oedema, and gastrointestinal fracas have also been witnessed. Diagnosis is directed by history and consideration. The symptoms and clinical signs do not have adequate positive or negative prognostic value, and therefore laboratory testing is needed for dependable diagnosis. Laboratory testing includes polymerase chain reaction (PCR) of ZIKAV RNA. There is formerly no vaccine against ZIKAV, nor definite antiviral for the management of ZIKAV. Treatment is suggestive. Vector control by insecticides and removal of small pools of still water, the breeding sites for Aedes, is being instituted on a local level.
\end{abstract}

occurred in French Polynesia Cook Islands [3], Easter Island [4], New Caledonia [5] and latest the Americas. [6]

\section{Search Policy/Selection Criteria}

We used the keywords Zika, ZIKV, ZIKAV, and Zika virus in search bar of Google and PubMed. We look over all literature published through November 30, 2016. The search comprised English and other foreign language articles, which were computer decoded. 


\section{Virology and Pathogenesis}

Zika virus (ZIKAV) is a positive-sense single-stranded RNA virus in the family Flaviviridae which includes several other mosquitos borne viruses of clinical status (e.g., DENV, WNV, and yellow fever virus [YFV]) [7]. Like other flaviviruses, ZIKAV is made up of two noncoding regions ( $5^{\prime}$ and $3^{\prime}$ ) that verge an open reading frame, which put into code a polyprotein smote into the capsid, precursor of membrane, envelope, and 7 nonstructural proteins [8]. A study ZIKAV's molecular evolution, based on viral strains collected from 4 countries in West Africa during 1947-2007, identified several sites within the Zika viral genome that were under strong negative miscellany pressure. This finding proposes frequent purging of deleterious polymorphisms in functionally essential genes and the likelihood of recombination, which occurs rarely among flaviviruses [9]. After mosquito inoculation of a human host, cellular entry likely look like that of other flaviviruses, whereby the virus enters skin cells through cellular receptors, enabling migration to the lymph nodes and blood circulation. Few studies have investigated the pathogenesis of ZIKAV infection. One study showed that human skin fibroblasts, keratinocytes, and immature dendritic cells allow entry of ZIKAV. Several entry and adhesion factors (e.g., AXL receptor tyrosine kinase) enable infection, and cellular autophagy, needed for flaviviral replication, develops ZIKAV replication in skin fibroblasts [10]. After cellular entry, flaviviruses typically replicate within endoplasmic reticulum-derived vesicles. However, ZIKAV antigens were found exclusively in the nuclei of infected cells; this finding suggests a location for replication that differs from that of other flavivi $\neg$ ruses and merits further exploration [11].

\section{Transmission}

Zika virus, like other flaviviruses, is pass on by mosqui-toes, primarily of the Aedes (Stegomyia) genus. The Ae. aegypti mosquito acts to be the major vector in Asia [12]. Zika virus has been detected in wild-caught Ae. aegypti mosquitoes, which laboratory trials have shown to be capable of pass on Zika virus $[13,14]$. Aedes mosquitoes are widely distributed worldwide, and natural habitats of most species are warm tropical and sub-tropical regions [15-17]. Mosquito getting hold of the virus likely occurs during a blood meal; after endorsement, the virus replicates and is pass on to a reservoir animal at the next blood mealtime [18]. Isolation of the virus or of anti-Zika virus antibodies from various non-human primates and other wild and native animals suggests several animal reservoirs. Other nonvector modes of Zika virus transmission include congenital, perinatal [19], and sexual [20]. Possible transmission by blood transfusion [21,22], animal bite [23]. Intrauterine transmission is supported by the finding of Zika virus RNA by reverse transcription PCR (RT-PCR) in amniotic fluid of 2 mothers with symptoms of Zika virus infection during pregnancy; both delivered babies with microcephaly [24]. Viral RNA, but not culturable virus, has been detected in breast milk [25], but transmission by breast-feeding has not been reported.
Two cases of possible transfusion-transmitted (TT) Zika virus were reported in Brazil [21]. Furthermore, during the French Polynesia outbreak, a study found that $42(2.8 \%)$ of 1,505 subclinical blood donors were positive for Zika virus by RT-PCR; 11 donors pronounced a Zika fever-like syndrome 3-10 days after donation [20].

\section{Clinical Manifestations}

In humans, the incubation period from mosquito bite to symptom commencement is 3-12 days. Infection is likely subclinical in $80 \%$ of cases [23,24]. Zika virus infections seem either to be subclinical (possibly in as many as $80 \%$ of infections) or to cause a trifling illness after an incubation period of 3 to 12 days. Symptoms, which last for almost two to seven days include fever, conjunctivitis, arthralgia, myalgia, and pervasive rash, which may be itchy. Headache, retro-orbital pain, peripheral oedema, and gastrointestinal fracas have also been witnessed. Only one study has examined the proportion of infections that produce symptoms. A serological survey during the Yap outbreak found that only 19\% of partakers with IgM antibodies against Zika virus stated rash, joint pains, or conjunctivitis that were probably attributable to Zika virus infection. Whether the remaining infected participants experienced any other symptoms was not reported [23]. Observation of Zika viraemia in 31 French Polynesian blood donors who reported no symptoms, during or after blood donation, suggests that asymptomatic infection does occur [20]. Shock and hemorrhage occur with other flaviviruses such as dengue, but they have not been documented in Zika virus infection. Severe acute illness seems to be rare. Fewer than 10 possible Zika related deaths have been reported in adults, and an additional three deaths from Guillain-Barré syndrome have arisen in those who had symptoms of Zika infection [27,28].

\section{Diagnosis}

The clinical picture of Zika virus infection is alike to that of former mosquito borne viruses such as dengue and chikungunya. Which often co-mingle in the zones, where Zika virus is endemic. The differential diagnosis of Zika virus infection is wide. Diagnosis is directed by history (travel, sexual behaviors, and interaction with other causes of infection) and consideration. Additionally to dengue and chikungunya, other diagnoses that should be considered include HIV seroconversion, measles, scarlet fever, rickettsial infection, leptospirosis, parvovirus, enterovirus, rubella, and secondary syphilis. The symptoms and clinical signs do not have adequate positive or negative prognostic value, and therefore laboratory testing is needed for dependable diagnosis.

\subsection{Laboratory Testing}

Conclusive diagnosis is based on recognition of Zika virus RNA in blood (serum or, ideally, EDTA treated plasma) and other body fluids by polymerase chain reaction (PCR). Subsequently to the acute phase, diagnosis by antibody detection in serum samples is conceded by substantial cross reactivity with antibodies to other flaviviruses; false positive results can be comprehended with past 
dengue infection or previous yellow fever vaccination [29]. Details are shown in Table:

\begin{tabular}{|c|c|c|}
\hline Sample & Test & Timing \\
\hline Blood & $\begin{array}{l}\text { Polymerase chain } \\
\text { reaction }\end{array}$ & $\begin{array}{l}\text { Usually }<5 \quad \text { days } \\
\text { (occasionally up to } 8 \text { days) } \\
\text { from symptom onset. [28] }\end{array}$ \\
\hline Serum & $\begin{array}{l}\text { IgM antibody } \\
\text { detection }\end{array}$ & $\begin{array}{l}\text { Measureable } 4-7 \text { days from } \\
\text { symptom beginning and } \\
\text { continues for } 2-12 \text { weeks. } \\
{[29]}\end{array}$ \\
\hline Saliva & $\begin{array}{l}\text { Polymerase chain } \\
\text { reaction }\end{array}$ & $\begin{array}{l}\text { Usually }<5 \text { days (seldom up } \\
\text { to } 8 \text { days) from symptom } \\
\text { commencement. [28] }\end{array}$ \\
\hline Semen & $\begin{array}{l}\text { Polymerase chain } \\
\text { reaction }\end{array}$ & $\begin{array}{l}\text { Very limited data: RNA has } \\
\text { been spotted at } 62 \text { days after } \\
\text { symptom onset in one case. } \\
{[30]}\end{array}$ \\
\hline Urine & $\begin{array}{l}\text { Polymerase chain } \\
\text { reaction }\end{array}$ & $\begin{array}{l}\text { Very limited data: single } \\
\text { study ( } 6 \text { patients) - positive } \\
\text { in } 6 / 6 \text { at } 10 \text { days from } \\
\text { symptom commencement, } \\
\text { and } 1 / 6 \text { quiet positive at } 30 \\
\text { days. [31] }\end{array}$ \\
\hline
\end{tabular}

\section{Management and Prevention}

There is formerly no vaccine against Zika virus, nor definite antiviral for the management of Zika virus. Treatment is suggestive, although it is not known what agents are prime for treating the fever, itch, and arthralgia. Minimization of the gamble of mosquito bites is advised by taxing long sleeves and khakis and using mosquito repellents [34].

Vector control by insecticides and removal of small pools of still water, the breeding sites for Aedes, is being instituted on a local level. Trials of the release of treated sterile mosquitoes are being deliberated by WHO.

\section{Recommendation}

1. Promote awareness campaign for prevention of Zika virus in public by eradication of Mosquito habitat.

2. Development of vaccine for the treatment of Zika virus.

\section{Conflict of Interest}

The authors declare no conflict of interest.

\section{Acknowledgment}

Special thanks to Dr. Jabar Zaman Khan Khattak for appreciation and guidance.

\section{References}

[1] Dick GW, Kitchen SF, Haddow AJ. Zika virus. I. Isolations and serological specificity. Trans R Soc Trop Med Hyg. 1952;46:509-20. http://dx.doi.org/10.1016/0035-9203(52)90042-4

[2] MacNamara FN. Zika virus: a report on three cases of human infection during an epidemic of jaundice in Nigeria. Trans R Soc Trop Med Hyg. 1954;48:139-45. http://dx.doi.org/10.1016/0035-9203(54)90006-1

[3] Roth A, Mercier A, Lepers C, Hoy D, Duituturaga S, Benyon E,et al. Concurrent outbreaks of dengue, chikungunya and Zika virus infections - an unprecedented epidemic wave of mosquito-borne viruses in the Pacific 2012-2014. Euro Surveill. 2014;19:20929.

[4] Tognarelli J, Ulloa S, Villagra E, Lagos J, Aguayo C, Fasce R, et al. A report on the outbreak of Zika virus on Easter Island, South Pacific, 2014. Arch Virol. 2016;161:665-8. http://dx.doi.org/ 10.1007/s00705015-2695-5

[5] Dupont-Rouzeyrol M, O'Connor O, Calvez E, Daurès M, John M, Grangeon JP, et al. Co-infection with Zika and dengue viruses in 2 patients, New Caledonia, 2014. Emerg Infect Dis. 2015;21:381-2. http://dx.doi.org/10.3201/eid2102.141553

[6] Fauci AS, Morens DM. Zika virus in the Americas-yet another arbovirus threat. N Engl J Med. 2016;374:601-4. http://dx.doi.org/ 10.1056/NEJMp1600297

[7] Lanciotti RS, Kosoy OL, Laven JJ, Velez JO, Lambert AJ, Johnson AJ, et al. Genetic and serologic properties of Zika virus associated with an epidemic, Yap State, Micronesia, 2007. Emerg Infect Dis. 2008; 14:1232-9. http://dx.doi.org/10.3201/eid1408.080287

[8] Kuno G, Chang GJ. Full-length sequencing and genomic characterization of Bagaza, Kedougou, and Zika viruses. Arch Virol. 2007;152:687-96. http://dx.doi.org/10.1007/s00705-006-0903-Z

[9] Faye O, Freire CC, Iamarino A, Faye O, de Oliveira JV, Diallo M, et al. Molecular evolution of Zika virus during its emergence in the 20(th) century. PLoS Negl Trop Dis. 2014;8:e2636. http://dx.doi.org/ 10.1371/journal.pntd.0002636

[10] Hamel R, Dejarnac O, Wichit S, Ekchariyawat P, Neyret A, Luplertlop $\mathrm{N}$, et al. Biology of Zika virus infection in human skin cells. J Virol. 2015;89:8880-96. http://dx.doi.org/10.1128/JVI.00354-15

[11] Buckley A, Gould EA. Detection of virus-specific antigen in the nuclei or nucleoli of cells infected with Zika or Langat virus. J Gen Virol. 1988;69:1913-20. http://dx.doi.org/10.1099/0022-1317-69-8-1913

[12] Olson JG, Ksiazek TG, Suhandiman, Triwibowo. Zika virus, a cause of fever in Central Java, Indonesia. Trans R Soc Trop Med Hyg. 1981;75:389-93. http://dx.doi.org/10.1016/0035-9203(81)90100-0

[13] Diallo D, Sall AA, Diagne CT, Faye O, Faye O, Ba Y, et al. Zika virus emergence in mosquitoes in southeastern Senegal, 2011. PLoS One. 2014;9:e109442. http://dx.doi.org/10.1371/journal.pone.0109442

[14] Boorman JP, Porterfield JS. A simple technique for infection of mosquitoes with viruses; transmission of Zika virus. Trans R Soc Trop Med Hyg. 1956;50:238-42. http://dx.doi.org/10.1016/00359203(56)90029-3

[15] Ledermann JP, Guillaumot L, Yug L, Saweyog SC, Tided M, Machieng P, et al. Aedes hensilli as a potential vector of Chikungunya and Zika viruses. PLoS Negl Trop Dis. 2014;8:e3188. http://dx.doi.org/10.1371/journal.pntd.0003188

[16] Kraemer MU, Sinka ME, Duda KA, Mylne A, Shearer FM, Brady OJ, et al. The global compendium of Aedes aegypti and Ae. albopictus occurrence. Sci Data. 2015;2:150035. http://dx.doi.org/10.1038/sdata.2015.35

[17] Gaffigan TVWR, Pecor JE, Stoffer JA, Anderson T. Systematic catalog of culicidae. Suitland (MD): Smithsonian Institution; Silver Spring (MD): Walter Reed Army Institute of Research; 2016 [cited 2016 Feb 10]. http://mosquitocatalog.org/

[18] Haddow AD, Schuh AJ, Yasuda CY, Kasper MR, Heang V, Huy R, et al. Genetic characterization of Zika virus strains: geographic expansion of the Asian lineage. PLoS Negl Trop Dis.

[19] Musso D, Roche C, Robin E, Nhan T, Teissier A, Cao-Lormeau VM. Potential sexual transmission of Zika virus. Emerg Infect Dis. 2015;21:359-61. http://dx.doi.org/10.3201/eid2102.141363

[20] Musso D, Nhan T, Robin E, Roche C, Bierlaire D, Zisou K, et al. Potential for Zika virus transmission through blood transfusion demonstrated during an outbreak in French Polynesia, November 2013 to February 2014. Euro Surveill. 2014;19:20761. http://dx.doi.org/10.2807/1560-7917.ES2014.19.14.20761

[21] US Food and Drug Administration. Recommendations for donor screening, deferral, and product management to reduce the risk of transfusion transmission of Zika virus, recommendations for industry. 2016 Feb 16 [cited $2016 \quad$ Feb 16 ] 
http://www.fda.gov/downloads/BiologicsBloodVaccines/GuidanceCo mplianceRegulatoryInformation/Guidances/Blood/UCM486360.pdf

[22] Leung GH, Baird RW, Druce J, Anstey NM. Zika virus infection in Australia following a monkey bite in Indonesia. Southeast Asian J Trop Med Public Health. 2015;46:460-4.

[23] Duffy MR, Chen TH, Hancock WT, Powers AM, Kool JL, Lanciotti RS, et al. Zika virus outbreak on Yap Island, Federated States of Micronesia. N Engl J Med. 2009;360:2536-43.

[24] Ioos S, Mallet HP, Leparc Goffart I, Gauthier V, Cardoso T, Herida M. Current Zika virus epidemiology and recent epidemics. Med Mal Infect. 2014;44:302-7. http://dx.doi.org/ 10.1016/j.medmal.2014.04.008

[25] Oliveira Melo AS, Malinger G, Ximenes R, Szejnfeld PO, Alves Sampaio S, Bispo de Filippis AM. Zika virus intrauterine infection causes fetal brain abnormality and microcephaly: tip of the iceberg? Ultrasound Obstet Gynecol. 2016;47:6-7.

[26] Besnard M, Lastere S, Teissier A, Cao-Lormeau V, Musso D. Evidence of perinatal transmission of Zika virus, French Polynesia, December 2013 and February 2014. Euro Surveill. 2014;19:20751

[27] World Health Organization. Zika virus: news and updates. Accessed 19 February 2016.www.who.int/emergencies/zika-virus/timelineupdate/en/.

[28] Pan American Health Organization. Epidemiological alert: neurological syndrome, congenital malformations, and Zika virus infection. Implications for public health in the Americas. 1 December 2015. www.paho.org/hq/index.php?option=com docman\& task $=$ doc view\&Itemid $=270 \&$ gid $=32405 \&$ lang $=e n$.

[29] Charrel RN, Leparc-Goffart I, Pas S, de Lamballerie X, Koopmans M, Reusken C. State of knowledge on Zika virus for an adequate laboratory response. Bull World Health Organ 2016; doi:10.2471/BLT.16.171207.

[30] Musso D, Roche C, Nhan TX, Robin E, Teissier A, Cao-Lormeau VM. Detection of Zika virus in saliva. J Clin Virol 2015;68:53-5. doi:10.1016/j.jev.2015.04.021. 26071336.

[31] Centres for Disease Control. Revised diagnostic testing for Zika, chikungunya, and dengue viruses in US Public Health Laboratories. Released 7 February 2016. Accessed 12 February 2016. www.cdc.gov/zika/pdfs/denvchikvzikv-testing-algorithm.pdf

[32] Atkinson B, Hearn P, Afrough B, et al. Detection of Zika virus in semen[letter]. Emerg Infect Dis 2016. Accessed 20 February 2016. doi:10.3201/eid2205.160107

[33] Gourinat AC, O'Connor O, Calvez E, Goarant C, Dupont-Rouzeyrol M. Detection of Zika virus in urine. Emerg Infect Dis 2015;21:84-6. doi:10.3201/eid2101.140894. 25530324.

[34] Stanczyk NM, Behrens RH, Chen-Hussey V, Stewart SA, Logan JG. Mosquito repellents for travellers. BMJ 2015;350:h99. doi:10.1136/bmj.h99. 25698775. 